(4) Early dialysis to remove isopropyl alcohol (King et al., 1970).

(5) Intermittent positive pressure respiration should be considered to support the patient while other measures are being undertaken.

\section{Acknowledgments}

We wish to thank Dr B. J. Jordan of Reckitt \& Colman for the measurement of PCMX and isopropyl alcohol. Our thanks are also due to the Poisons Reference Service, New Cross Hospital, for screening urine and plasma for common poisons.

\section{References}

AdELSON, L. (1962) Fatal intoxication with isopropyl alcohol (rubbing alcohol). The American Journal of Clinical Pathology, 38, 144.

BERRY, D.J. \& GRoove, J. (1973) Emergency toxicological screening for drugs commonly taken in overdose. Journal of Chromatography, 80, 205.

CoOPer, P. (1958) Poisoning by Drugs and Chemicals, 1st Edn, p. 60. Alchemist Publications, London.

Dunhill, M.S. (1974) A review of the pathology and pathogenesis of acute renal failure due to tubular necrosis. Journal of Clinical Pathology, 27, 2.

Flanagan, R. \& Withers, G. (1972) A rapid micromethod for the screening and measurement of barbiturates and related compounds in plasma by gas-liquid chromatography. Journal of Clinical Pathology, 25, 899.
Freireich, A.W., Cinque, T.J., Xanthaky, G. \& Landau, D. (1967) Hemodialysis for isopropanol poisoning. New England Journal of Medicine, 277, 699.

GoRnel, D.L. \& Goldman, R. (1968) Acute renal failure following hexol-induced abortion. Journal of the American Medical Association, 203, 168.

GRAHAM, J.D.P. (1962) Diagnosis and Treatment of Acute Poisoning, 1st Edn, pp. 282-283. Oxford University Press, London.

Juncos, L. \& TAguchi, J.L. (1968) Isopropyl alcohol intoxication. Journal of the American Medical Association, 204, 186.

King, L.H., Bradley, K.P. \& Shires, D.L. (1970) Hemodialysis for isopropyl alcohol poisoning. Journal of the American Medical Association, 211, 1855.

MARTINDAle (1972) The Extra Pharmacopoeia (Ed. by N. W. Blacon), 26th Edn, pp. 183, 184, 185, 211, 1244. The Pharmaceutical Press, London.

OLSEN, T.S. (1967) Ultrastructure of the renal tubules in acute renal insufficiency. Acta pathologica et microbiologica scandinavica, 71, 203.

TuRTle, W.R.M. \& Dolan, T. (1922) A case of rapid and fatal absorption of carbolic acid through the skin. Lancet, ii, 1273.

Williams, R.T. (1959) Detoxification Mechanisms, 2nd Edn, p. 159. Chapman and Hall, London.

ZONDEK, B. (1942a) The excretion of halogenized phenols and their use in the treatment of urogenital infections. Journal of Urology, 48, 747.

ZONDEK, B. (1942b) Chemotherapeutical use of halogenized phenols as internal disinfectants. Nature. London, 149, 334.

\title{
Spontaneous rupture of the abdominal aorta
}

\author{
T. G. Williams* \\ M.B., B.Chir., F.R.C.S.
}

\section{The Ipswich Group of Hospitals}

\section{Summary \\ Fatal spontaneous rupture of the lower abdominal aorta in a previously healthy 61-year-old woman is reported; the possibility that she had the Ehlers- Danlos syndrome is discussed.}

\section{Introduction}

Rupture of the abdominal aorta has not hitherto been reported in the absence of trauma, hypertension, overt aortic disease or prior clinical evidence of a connective tissue disorder. None of these features was present in the following case.

* Present address: 15 Thorley Gardens, Pyrford Road, Pyrford, Surrey GU22 8UL.

\section{Case report}

A 61-year-old woman, previously normotensive and in excellent physical health although treated with amitriptyline for a year because of depression, was admitted urgently with a 12-hr history of epigastric pain radiating to the back. She had never previously been in hospital and there was no relevant family history. She had always bruised easily, as when her dog jumped at her or someone held her arm. On two occasions her gums had to be stitched because of persistent bleeding after tooth extraction. She had a normal 30-year-old son and two subsequent miscarriages, all delivered uneventfully at home. 
On admission she was conscious but pale with BP $90 / 60 \mathrm{mmHg}$; pulse, 70 beats $/ \mathrm{min}$ and sublingual temperature $36^{\circ} \mathrm{C}$. She was $1.6 \mathrm{~m}$ tall and weighed $73 \mathrm{~kg}$; she was plump, fair-haired and fairskinned and had a dozen small bruises on her trunk and limbs. There was a healed unpigmented scar on the left shin. Joint laxity was not sought. She had epigastric tenderness with mild abdominal distension and shifting dullness; bowel sounds were present. There were no other physical signs and an ECG and chest and abdominal X-rays were normal; $\mathrm{Hb}$ $11 \cdot 7 \mathrm{~g} / \mathrm{dl}$.

Massive internal bleeding was not suspected. Pending investigation, a saline infusion was started but the patient died $1 \mathrm{hr}$ after admission. At postmortem she was found to have a circular perforation with a small vertical tear in the anterior wall of the aorta $3 \mathrm{~cm}$ above the aortic bifurcation (Fig. 1). The peritoneal cavity was full of blood clot. The aorta, its major branches and the coronary arteries were strikingly free of visible atheroma. The aortic wall was thin and histologically the intima showed mild atheroma. The media was normal apart from a little hyaline material separating some muscle

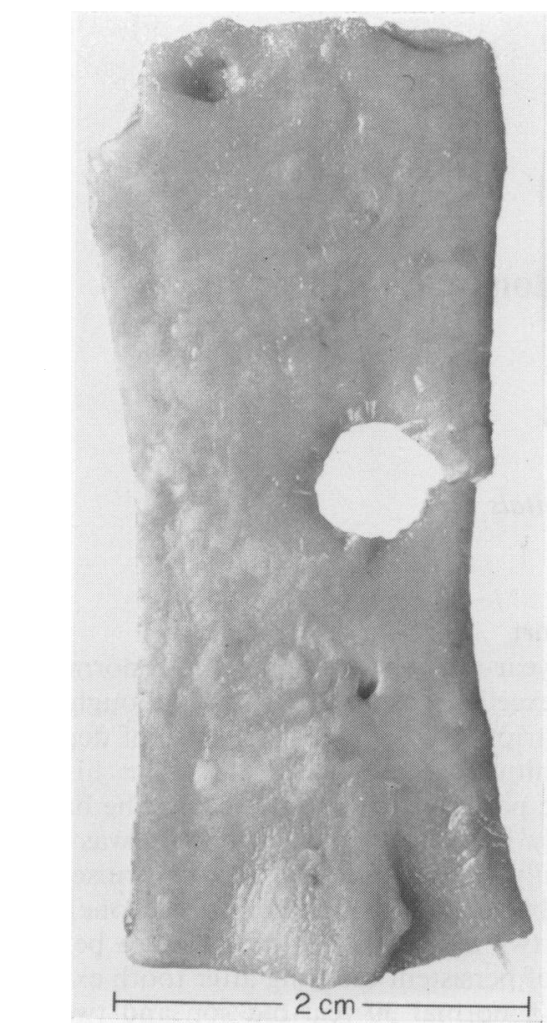

Fig. 1. The anterior aortic perforation seen from its intimal aspect. fibres. The elastic structure was normal and there was no evidence of mucoid degeneration or aortitis. All other viscera were normal and not obviously friable.

\section{Discussion}

Spontaneous rupture of the aorta has not previously been described in the absence of an obvious predisposing factor. Mirza, Hassan and Jordan (1972), for instance, discussed a 9-year-old boy whose hypoplastic lower abdominal aorta ruptured on the third day after successful resection of a juxtaductal coarctation, his post-operative brachial blood pressure being 170/120 mmHg. Eastcott (1973) reported aortic rupture just above the bifurcation in a 52-year-old man 6 weeks after right hemicolectomy for recurrent starch granulomata, the perforation occurring through an arteriosclerotic ulcer close to an abscess.

Weakness of the aorta, usually presenting as thoracic dissection due to cystic medionecrosis, occurs in the Marfan and Ehlers-Danlos syndromes (McKusick, 1972). Arterial bleeding is a well documented and frequently lethal complication of the ecchymotic or vascular type of Ehlers-Danlos syndrome (Beighton, 1968) which is characterized by easy bruising, digital joint laxity and a thin, pale, transparent skin through which the subdermal venous plexus is readily seen (Barabas, 1967). Vascular complications have mainly been reported from male teenagers with 'cigarette paper' skin which bruised and lacerated easily, healed poorly and did not tolerate sutures (Mories, 1960; McFarland and Fuller, 1964; Barabas, 1967; McKusick, 1972). Adult women, usually with other vascular anomalies, have also had fatal vascular catastrophes (Graf, 1965; Bannerman, Graf and Upson, 1967; Barabas, 1967; Barabas, 1972; Beighton, 1970). In all these reports (Table 1) other obvious stigmata of the Ehlers-Danlos syndrome were present and in almost every case medical attention was necessary several years before the final presentation.

Surgery in the Ehlers-Danlos syndrome is often complicated by serious bleeding from friable major vessels, persistent oozing from small vessels and haematoma formation, as well as by difficulties with the incision, closure and healing of skin (Rybka and O'Hara, 1967; Beighton and Horan, 1969). Arteriography is likewise hazardous (Schoolman and Kepes, 1967) although successfully undertaken by Rubinstein and Cohen (1964) and Bopp, Hatam and Bussat (1965). Spontaneous rupture of the aorta in the Ehlers-Danlos syndrome has invariably proved fatal but Barabas (1972) nevertheless urges urgent laparotomy in the patient with an abdominal vascular catastrophe in case the bleeding is from a remediable source, such as the splenic artery. 
TABLE 1. Fatal vascular catastrophes in the Ehlers-Danlos syndrome

\begin{tabular}{|c|c|c|c|c|}
\hline Author & Age & Sex & Cause of death & Diagnostic clinical features \\
\hline Mories (1960) & 15 & $\mathbf{M}$ & $\begin{array}{l}\text { Ruptured right femoral artery } 18 \\
\text { days after falling off bicycle }\end{array}$ & $\begin{array}{l}\text { Thin papery scars over patella. Hyper- } \\
\text { extensible fingers. Previous haematoma } \\
\text { in left thigh }\end{array}$ \\
\hline $\begin{array}{l}\text { McFarland and Fuller } \\
\text { (1964) }\end{array}$ & 12 & $\mathbf{M}$ & $\begin{array}{l}\text { Popliteal bleeding (two previous } \\
\text { similar episodes) }\end{array}$ & $\begin{array}{l}\text { Many lacerations and dislocations. } \\
\text { Multiple gaping scars over the elbows } \\
\text { and knees. Skin hyperextensible }\end{array}$ \\
\hline $\begin{array}{l}\text { McFarland and Fuller } \\
\text { (1964) }\end{array}$ & 17 & $\mathbf{M}$ & $\begin{array}{l}\text { Spontaneous rupture of the right } \\
\text { subclavian artery }\end{array}$ & $\begin{array}{l}\text { Bruising and excessive bleeding from } \\
\text { minor cuts. Scars over bony pro- } \\
\text { minences. Hyperextensible joints }\end{array}$ \\
\hline Lynch et al. (1965) & 14 & $\mathbf{M}$ & Dissection of lower thoracic aorta & $\begin{array}{l}\text { Hypermobile joints. Hyperelastic skin } \\
\text { with bruising tendency and slow } \\
\text { healing }\end{array}$ \\
\hline Graf (1965) & 24 & $\mathbf{F}$ & Ruptured left ventricle & $\begin{array}{l}\text { Easy bruising. Transparent extensible skin. } \\
\text { Hypermobile fingers }\end{array}$ \\
\hline $\begin{array}{l}\text { Bannerman, Graf and } \\
\text { Upson (1967) }\end{array}$ & 43 & $\mathbf{F}$ & Ruptured splenic artery & $\begin{array}{l}\text { Thin skin with prominent venous network. } \\
\text { Previous left carotid-cavernous fistula } \\
\text { and multiple aneurysms }\end{array}$ \\
\hline McKusick (1972) & 15 & $\mathbf{M}$ & Aortic dissection & Many scars. Cut easily and healed poorly \\
\hline McKusick (1972) & 24 & $\mathbf{M}$ & Dissection of renal artery & $\begin{array}{l}\text { Short stature. Arachnodactyly. Easy } \\
\text { bruising }\end{array}$ \\
\hline McKusick (1972) & 14 & $\mathbf{M}$ & $\begin{array}{l}\text { Thoracic and abdominal aortic } \\
\text { dissection }\end{array}$ & $\begin{array}{l}\text { Numerous scars on knees and ankles. } \\
\text { Five previous spontaneous perforations } \\
\text { of the colon }\end{array}$ \\
\hline Barabas (1967) & 30 & $\mathbf{F}$ & $\begin{array}{l}\text { Spontaneous rupture of the aorta. } \\
\text { Previous haematomata in right } \\
\text { iliac and both popliteal fossae }\end{array}$ & $\begin{array}{l}\text { Cut and bruised easily since childhood. } \\
\text { Skin transparent, hyperextensible and } \\
\text { obvious subdermal venous pattern. } \\
\text { Hypermobile hands. Episodes of severe } \\
\text { abdominal pain }\end{array}$ \\
\hline Beighton (1970) & 37 & $\mathbf{F}$ & Torn internal iliac artery & $\begin{array}{l}\text { Thin, lax skin. Arachnodactyly. Hyper- } \\
\text { mobile joints. Long perineal tears at } \\
\text { parturition. Previous laparotomy for } \\
\text { abdominal bleeding. Previous carotid- } \\
\text { cavernous fistula }\end{array}$ \\
\hline $\begin{array}{l}\text { Schoolman and Kepes } \\
\text { (1967) }\end{array}$ & 39 & $\mathbf{F}$ & $\begin{array}{l}\text { Ascending aorta torn during } \\
\text { aortography for carotid- } \\
\text { cavernous fistula }\end{array}$ & $\begin{array}{l}\text { Bruising tendency and hypermobile joints. } \\
\text { Severe perineal tear at childbirth }\end{array}$ \\
\hline
\end{tabular}

The aorta has often been noted as delicate or hypoplastic in the Ehlers-Danlos syndrome. Histologically, large arteries have been variously described as normal (McFarland and Fuller, 1964) or showing such changes as thinning of the media (Barabas, 1972), degeneration and hyalinization of collagen (Mories, 1960) or cystic medionecrosis resembling that found in the Marfan syndrome (McKusick, 1972). Whatever the obvious changes in the media, McKusick (1972) has postulated the fundamental defect as a genetically distinct sub-microscopic disorder of collagen, usually inherited as an autosomal dominant trait although Bannerman et al.
(1967) suggest that some cases may be autosomal recessive.

\section{Conclusion}

Spontaneous perforation of the thin but otherwise normal aorta in this report implies inherent weakness of the aortic wall. The patient's fair skin and multiple bruises suggest that she had the vascular (ecchymotic) form of Ehlers-Danlos syndrome although her late and fatal presentation appears unique.

\section{Acknowledgment}

I thank Mr K. C. D. Gordon for permission to report his case. 


\section{References}

Bannerman, R.M., Graf. C.J. \& Upson, J.F. (1967) Ehlers-Danlos syndrome. British Medical Journal, 3, 558,

Barabas, A.P. (1967) Heterogeneity of the Ehlers-Danlos syndrome: description of three clinical types and a hypothesis to explain the basic defect(s). British Medical Journal, 2, 612 .

Barabas, A.P. (1972) Vascular complications in the EhlersDanlos syndrome. Journal of Cardiovascular Surgery, 13, 160.

Beighton, P. (1968) Lethal complications of the EhlersDanlos syndrome. British Medical Journal, 3, 656.

Beighton, P. (1970) The Ehlers-Danlos Syndrome. William Heinemann, London.

Beighton, P. \& Horan, F.T. (1969) Surgical aspects of the Ehlers-Danlos syndrome. British Journal of Surgery, 56, 255.

Bopp, P., Hatam, K. \& Bussat, P. (1965) Cardiovascular aspects of the Ehlers-Danlos syndrome. Circulation, 32, 602.

EastcotT, H.H.G. (1973) Arterial Surgery. Second Edn, p. 135. Pitman Medical, London.

Graf, C.J. (1965) Spontaneous carotid-cavernous fistula. Archives of Neurology, 13, 662.
Lynch, H.T., Larsen, A.L., Wilson, R. \& Magnuson, C.L. (1965) Ehlers-Danlos syndrome and 'congenital' arteriovenous fistulae. Journal of the American Medical Association, 194, 1011.

McFarland, W. \& Fuller, D.E. (1964) Mortality in Ehlersr Danlos syndrome due to spontaneous rupture of large arteries. New England Journal of Medicine, 271, 1309.

McKusick, V.A. (1972) Heritable Disorders of Connective Tissue. Third Edn, pp. 292-371. C. V. Mosby, St Louis.

Mirza, M., Hassan, A. \& Jordan, P. (1972) Spontaneous rupture of the abdominal aorta. Annals of Thoracic Surgery, 13, 261.

MORIES, A. (1960) Ehlers-Danlos syndrome with a report of a fatal case. Scottish Medical Journal, 5, 269.

Rubinstein, M.K. \& Cohen, N.H. (1964) Ehlers-Danlos syndrome associated with multiple intra-cranial aneurysms. Neurology, 14, 125.

RyBKA, F.J. \& O'HARA, E.T. (1967) Surgical significance of the Ehlers-Danlos syndrome. American Journal of Surgery, 113, 431.

Schoolman, A. \& KePes, J.J. (1967) Bilateral spontaneous carotid-cavernous fistulae in the Ehlers-Danlos syndrome. Journal of Neurosurgery, 26, 82.

\section{Acute appendicitis in association with non-obstructive carcinoma of the caecum}

\author{
D. G. WALLER* \\ M.B., B.S.
}

\section{Glasgow $\dagger$ F.R.C.S.}

\section{The London Hospital, Whitechapel, London}

\begin{abstract}
Summary
A case of carcinoma of the caecum is reported, which presented as acute appendicitis, although the carcinoma did not obstruct either the lumen of the appendix or the colon.

The prognosis for caecal or proximal colonic neoplasm presenting as appendicitis is poor. This is in part due to the association being missed at the initial laparotomy. It is suggested that a more aggessive attitude should be taken in the pre- and post-operative management of any patient over 50 years of age who presents with appendicitis. The difficulties of identifying a small tumour at laparotomy even if the mucosa can be palpated are emphasized.
\end{abstract}

\section{Introduction}

The association of carcinoma of the caecum and appendicitis is well recognized. Shears in 1906 was

\footnotetext{
* Present address: Department of Haematology, Southampton General Hospital, Hants.

$\dagger$ Present address: Department of Orthopaedics, University College Hospital, London.
}

the first to report a case, although reference had been made in textbooks before the report. However, by 1967 Runderman, Strawbridge and Bloom were able to collect only seventy-one cases from the world literature.

Appendicitis is caused by obstruction of the appendical lumen in over $50 \%$ of cases (Collins, 1939). As caecal neoplasma make up $6.5 \%$ of all colonic neoplasma (Hellsten and Ramstrom, 1951) it is, therefore, reasonable to suggest that the association of appendicitis and proximal colonic neoplasm occurs more commonly than the literature would suggest. Several mechanisms have been proposed whereby colonic neoplasia may cause inflammation of the appendix (Table 1). In previous reports, the most common cause of appendicitis in association with colonic neoplasia is obstruction of the lumen of the appendix by a caecal neoplasm, although lesions causing colonic obstruction may also lead to appendicitis (Miln and McLaughlin, 1969). The authors have added extralumenal obstruction as they feel that in the case described, obstruction was due to 